\title{
Human Rights and Refugee Protest against Immigration Detention: Refugees' Struggles for Recognition as Human
}

\author{
LUCY FISKE
}

\begin{abstract}
When detainees go on hunger strike or riot or occupy the roofs of detention centres, their actions are usually narrated by governments keen to discredit them and their actions as criminal and manipulative and evidence of their barbarity and difference. A secondary, counter-narration is provided by detainee supporters who explain the actions as evidence of detainees' distress and deteriorating mental health. The voices of the actors themselves, people held in detention and taking protest action, are rarely heard in depth. Drawing on in-depth interviews with refugees formerly held in Australian immigration detention centres, and the works of Hannah Arendt, this article argues that the experience of immigration detention is fundamentally dehumanizing and that while detainee protest was aimed at attaining certain material outcomes, it also served important existential functions. The fact of protest was a rejection of a powerless state, a way for detained refugees to experience their own agency and, with it, restoration of some of the "essential characteristics of human life" and a means to use their reduction to "bare humanity" as a basis for insisting upon a place in the polis.
\end{abstract}

\section{Résumé}

Lorsque ceux qui sont détenus s'engagent dans des grèves de faim ou des émeutes, ou encore occupent le toit des centres de détention, leurs actions sont reformulées par des gouvernements, motivés par le désir de les dénigrer, en récits qui mettent en évidence leur prétendue criminalité, leur volonté manipulatrice, leur barbarie et leur différence. Un deuxième courant qui va à l'encontre de ces récits est véhiculé par les sympathisants des détenus, et consiste à montrer que leurs actions découlent de la détresse qu'ils ressentent et de la détérioration de leur santé mentale. Cependant les voix des actants eux-mêmes, notamment ceux qui sont détenus et s'engagent dans des actions de contestation, se font rarement entendre d'une manière significative. En se basant sur des entrevues en profondeur avec des réfugiés détenus antérieurement dans des centres de détention pour immigrés en Australie, ainsi que sur l'œuvre de Hannah Arendt, cet article avance que l'expérience de la détention d'immigration est profondément déshumanisante, et que les actes de contestation de la part des détenus, bien qu'ils visaient dans un premier temps certains objectifs matériels, remplissaient également des fonctions existentielles importantes. Le fait de contestation représentait le rejet d'un état d'impuissance, un moyen par lequel les réfugiés détenus pouvaient ressentir leur propre volonté d'action, et conséquemment, un rétablissement de certaines "caractéristiques essentielles de la vie humaine» ("essential characteristics of human life"). C'était également une façon de se servir de leur réduction à un état d'humanité dénudée ("bare humanity") pour insister sur leur place dans le polis ou communauté politique dans lequel ils se trouvaient. 


\section{Introduction}

7 he use of immigration detention is on the rise globally. More than one million people pass through immigration detention centres in the United States, Canada, Australia, and Europe each year. ${ }^{1}$ They are held in over-crowded, dilapidated detention centres or in modern, purpose-built facilities designed as "super-max" prisons, allocated an identification number, subjected to arbitrary rules and sometimes to arbitrary and excessive use of force, and distanced from legal protections by their incarceration. They have little knowledge and little political voice: they are non-citizens, non-people. ${ }^{2}$ Life inside immigration detention centres is precarious, filled with uncertainty and monotony and, too often, degrading treatment. As the use of immigration detention has risen, so too has detainee protest. When detainees go on a hunger strike or riot or occupy the roofs of detention centres, their actions are usually narrated by governments keen to discredit them and their actions as criminal, manipulative, and evidence of their barbarity and difference. ${ }^{3}$ A secondary, counter-narration is provided by detainee supporters who explain the actions as evidence of detainees' distress and deteriorating mental health. The voices of the actors themselves, people held in detention and taking protest action, are rarely heard in any depth. Refugees are typically presented in popular discourse as either victims or villains and almost never as conscious agents.

While most OECD countries have administrative immigration detention, Australia is unique in that its immigration detention is both mandatory and indefinite. All people who do not have lawful status in the country are detained, regardless of individual characteristics or vulnerabilities (such as psychological or physical health, age, or flight risk). There are no statutory limits to detention and, unless there is ministerial intervention, detainees are typically held until granted a visa or removed from the country, a process that can take several months to several years. Detainees have no way of predicting how long they will be incarcerated.

This article arises from a four-year study of refugee protest against immigration detention in Australia based on in-depth interviews with formerly detained refugees, during which every respondent, without prompting, said, "I am human," or "We are human."4 Using Hannah Arendt's works on human rights and The Human Condition to analyze detainee testimony, I propose that the experience of immigration detention is fundamentally dehumanizing 6 and that while detainee protest was aimed at attaining certain outcomes such as obtaining access to telephones, halting forced removals, or affecting refugee status determination, it also served important existential functions. The fact of protest was a rejection of a powerless state, a way for detained refugees to experience their own agency and with it, restoration of some of the "essential characteristics of human life" and a means to use their reduction to "bare humanity" as a basis for insisting upon a place in the polis. A close reading of refugee protest gives insight into the daily relations and regimens of immigration detention centres, but also important philosophical and theoretical insights into understanding the human subject of human rights.

\section{The Human Condition and Human Rights}

"Respect. Just respect. When someone respect me I respect him, because the respect it's belong just to human. Animal won't respect you, animal will obey you, because you feed them. They don't know the respect. They walking with you, dog walking with you, suddenly without 'Excuse me' he just pee in the road. But a human, it's the respect between each other. So when we say that we are human, show some respect. That's it" (Osman).7

A recurring theme among refugees interviewed was a desire to be recognized as human. Embedded in these calls was an appeal to a shared or universal humanity and an implied belief that human status entails a guarantee of a minimum standard of treatment, an implicit acknowledgement of a human rights framework. At times respondents made overt pleas to human rights as a way to improve their situations, while at other times the inference of human rights was less explicit. Humanity and rights as referred to by refugees in immigration detention seldom arose from a substantive knowledge of international human rights laws and systems (although some participants in this research did have extensive knowledge of formal human rights systems). Detainees nonetheless found human rights to be a powerful language for articulating injustice. Every person interviewed in this research complained of feeling dehumanized and unrecognized in detention. Some compared their status to that of animals, inanimate objects, or death. Osman expressed his frustration at being reduced to a status lower than an animal: "When officer call me '0276,' I said, 'Oh God! I've got name. Your donkey or your dog and your cat has name. I'm a human like you. Don't call me by number."”

Detainees' physical survival needs were met with shelter, food, and clothing, but former detainees testified that human life entails more than physical survival. An existential aspect to human life that distinguishes humans from animals cannot be reduced to mere biology. Detainee cries of "We are human" were appeals for recognition of such an aspect. Former detainees interviewed in this work, regardless of how much they knew about formal human rights systems, shared an unshakeable belief that to be humanmorally if not legally-entitled them to certain rights. 
Hannah Arendt's work provides a theoretical framework for better understanding why immigration detention is experienced as so utterly dehumanizing and for interrogating detainee protest as a way to resist dehumanizing regimes and insist upon a recognizably human life.

\section{Dehumanizing Categories}

Arendt makes a distinction between what and who a person is. ${ }^{8}$ A person may be identified and categorized as a woman, Jew, Muslim, asylum seeker, or "boatperson" from characteristics such as dress, appearance, or context, such as on an overcrowded boat off Australia's northern coast. ${ }^{9}$ However, she can reveal who she is in particular, only through her own speech and action. The individual characteristics that distinguish each unique person can be discerned only through the revelations of that person, gained intersubjectively through interaction and engagement on a basis of equality. The "what" of a person can only ever be an approximation of humanity, consisting of stereotypes into which individuals are grouped with little or no regard for the uniqueness of each person. To treat a person according to what rather than who she is, Arendt contends, dehumanizes the person. She is denied the opportunity to reveal herself to the world, denied entry to the public sphere as an initiating and equal person, and reduced to a representative sample of the category into which she has been placed: "If a Negro in a white community is considered a Negro and nothing else, he loses along with his right to equality that freedom of action which is specifically human; all his deeds are now explained as 'necessary' consequence of some 'Negro' qualities; he has become some specimen of an animal species called man."1o

When treated primarily or only as a representative of a group, such as "boatpeople," a person's humanness is not recognized and she is reduced to a state of biology. She then holds no specific value as an individual, and her life becomes unimportant and potentially superfluous. Detainees understood and felt this lack of individual recognition keenly. Dr. Aamer Sultan commented, “That's one of the arguments I used to leave with many Australians outside, that the government are doing that now to people who are in detention: outsiders, migrants, Arab, Muslim, it doesn't matter. What guarantee that they won't do the same to someone else outside? Started with the homeless people, the Aborigines in a way."

Aamer could see that when encountered only as a representative of a group - “Arab, Muslim”- he didn't matter and was interchangeable with "homeless people" or "Aborigines." Emad expressed a similar concern. He complained that when he was in detention, the authorities made no attempt to discern any individuality, but that instead detainees were treated as just that.
Not all people are the same. Mentally, some of the people can cope with the circumstance there. Some of them, the majority of them-especially kids and women-cannot. So the management and the immigration didn't take into consideration that the people are different. They behaved in a one rough manner, one rough standard towards all of the people, and that's completely wrong. You're being tough to everyone. You have to understand every person's need-or try to understand. Even if you fail, try to understand. Try to take some effort to understand. That we couldn't see, we didn't see at all actually. We just saw some ... a very hard-line treatment and it was typical every day, every morning, every night. They didn't try to investigate what's in our hearts or mind. And we believed that humans can, actually can, reach to the hearts and minds of the other humans. But unfortunately it wasn't the case at that time.

Ibrahim also expressed frustration at the sameness of all detainees when he said, "It's wrong. But for us, we been just all same. Refugee or criminal or whatever-you the same. Like the children, women, anyone." He complained that any individual speech or action in detention had no impact on the way in which he or his fellow detainees were treated. He, and those detained with him, had been categorized as "unlawful entrants" and would be treated accordingly until re-categorized as "refugee." At heart, it was this bureaucratic dehumanization that the cry "We are human" struggled against and that refugee protest sought to counter.

\section{The Right to Have Rights}

Arendt conceived of human rights in two groups. Civic rights are "all those rights which require the protection of a government,"11 including all the rights contained in international human rights treaties such as the right to adequate food and shelter, the right to vote, to education, to freedom of movement, and so on. Prior to this group of rights however, is "the right to have rights," which she defined as the right to "a place in the world which makes opinions significant and actions effective."12 For Arendt this meant that meaningful speech and action, and plurality based on equality and distinction are necessary elements for a human life to be recognizable as such and to rise above mere survival.

Speech and action are fundamental dimensions of the human condition and distinguish us from other animals. If we are deprived of the opportunity to speak and act, and to engage with other human beings on a basis of equality, we are denied an essential aspect of our humanity. Speech and action become meaningful only when they are recognized by others, and this recognition constitutes and conveys our equality and our membership in the polis. Conversely, when our speech and actions are ignored by those around us, we 
become a non-person and have no impact on the common world beyond the private sphere of personal relationships. It was precisely this non-existence that Farshid referred to when he said, "People's situation in detention was that you were the lost person, the forgotten person, you don't exist, you cannot change anything, and you have no power over anything."

Belonging to a political community and participating in the public life of that community is a fundamental aspect of the human condition. Humans are distinguished from gods and beasts by our capacity for action and our existence in plurality. Arendt argues that since Aristotle, humans have been "defined as ... commanding the power of speech and thought ... and as the 'political animal' ... one who lives in a community."13 Being a "political animal" is not the same as being a social animal, which requires individuals to live together for procreation or survival. Politics has an added existential depth and involves the capacity to organize and create a world of human affairs, the common world. It is this that distinguishes human life. ${ }^{14}$ Therefore, the loss of a political community means the loss of "some of the most essential characteristics of human life." 15

In order to understand how the loss of recognition in the public sphere equates to the loss of humanity, it is necessary to look in greater detail at two key aspects of Arendt's conception of the human condition; first, the human need for meaningful speech and action and, second, plurality, that consists of equality and distinction.

\section{Meaningful Speech and Action}

Arendt identifies meaningful speech and action as a necessary condition for a life that is "fully human" and enters the common world as an equal. It is through individual speech and action, recognized and judged by others, that each individual human being reveals her unique and distinct self to the world: "In acting and speaking, men show who they are, reveal actively their unique personal identities and thus make their appearance in the human world, while their physical identities appear without any activity of their own ... This disclosure of 'who' in contradistinction to 'what' somebody is-is implicit in everything somebody says and does. It can be hidden only in complete silence and perfect passivity." 16

But a life of silence and passivity is, according to Arendt "dead to the world." Actively participating in public life is necessary for human life to be distinct from "mere bodily existence," and it is through meaningful engagement with others as equals that human life distinguishes itself. ${ }^{17}$ Ismail remarked that if he had not protested against the regimen of detention, but instead had silently and passively accepted his position, he would cease to be alive in any meaningful sense: "Because if I didn't do those things, nothing different between me and this table. With me? I got a soul. I got a mind. I got thinking."

Sayed expressed a similar opinion when he explained why he and others took action against detention: "That's what happens, that's the main purpose everybody do what they do. Otherwise there is no difference between the live and the dead you know. Otherwise I could be dead-nothing."

When someone's speech and action are not recognized, she is treated and judged, not according to who she is (through her words and deeds), but according to her membership in a category. This refusal to recognize someone's individuality is a refusal to recognize a fundamental aspect of her humanity and is profoundly dehumanizing. When Arendt speaks of the individual, it is not the pre-existing abstract autonomous individual of Enlightenment thought, upon which modern politics is based, but rather, she is referring to an ontologically intersubjective and interdependent individual. "The self for Arendt is the self of a human community that is formed through and cannot exist without interacting in the world." 18 The power of speech and action is not only a capacity for self-revelation, consisting of the disclosure of a pre-formed and complete self to a waiting world, but is simultaneously self-constituting. Humanity is fundamentally plural, and plurality is an inescapable and a desirable dimension of humanity.

\section{Plurality: Equality and Distinction}

Plurality, for Arendt, paradoxically consists of distinction and equality. Humans share certain essential characteristics, but unlike the potentially homogenizing force of universalist or essentialist arguments, Arendt's "human condition" is based on distinction, both of humans from other animals and of every human from every other human. "We are all the same, that is, human, in such a way that nobody is ever the same as anybody else who ever lived, lives, or will live."19 Every human is different and distinct, though we all share the capacity to initiate, to create, to think, to speak, and to act, and these capacities are core to human life. No two people are ever absolutely identical, and it is through the insertion of the individual self in the common or public world that each of us contributes to the human artifice, which constitutes the common world and ourselves at the same time. Plurality requires difference and multiplicity. A necessary tandem element of plurality is equality.

Equality, for Arendt, does not refer to the equal distribution of material goods, nor to an abstract equality inherent in the human condition, but equality as a political decision and as the basis for politics shaped by justice, rather than coercion or force: "We are not born equal; we become equal as members of a group on the strength of our decision to 
guarantee ourselves mutually equal rights. Our political life rests on the assumption that we can produce equality through organisation, because man can act in and change and build a common world, together with his equals and only with his equals." 20

Inequality and a lack of recognition of detainees' basic humanity shaped interactions between detainees and officials and was reinforced through every aspect of detention life. Food was raised as an issue by almost everyone interviewed. For Osman, the poor food was an issue of inequality. He complained to the detention manager and said, "The way you eat in your home, bring it to us." Most people expressed the lack of equality as a lack of respect. Ibrahim, when asked what he needed to feel human, responded, "To be respected as a human. To be treated as a human. So you can feel your humanity and dignity. It's very important. It's very simple too. That's what we were asking for, and unfortunately, we didn't find it. We found the opposite thing, which is they treated us as an animal, and maybe even the dog ... because the manager of the camp has a dog, and I think the dog, he was luckier than me. Seriously."

Arendt considered respect an essential foundation for politics that is based on mutual equality rather than force. She described respect as a public sphere sentiment that acts as a basis for human relationships, similar to the way in which love binds relationships in the private sphere: "Yet what love is in its own narrowly circumscribed sphere, respect is in the larger domain of human affairs. Respect, not unlike the Aristotelian philia politikē, is a kind of 'friendship' without intimacy and without closeness; it is a regard for the person from the distance which the space of the world puts between us, and in this regard is independent of qualities which we may admire or of achievements which we may highly esteem."21

In this light, the respect that Ibrahim and others said they needed in order to "feel human" can be understood as representing their equality and belonging. Because we are intersubjectively and interdependently constituted, a widespread lack of respect in the public sphere can easily lead to civic death, or what Farshid described as being "the lost person, the forgotten person, you don't exist.” A refusal to be lost or forgotten, to accept their civic non-existence, regardless of material outcomes, was a major motivation in much detainee protest action.

\section{Detainee Protest as Restoration to a "Human" Status}

Refugee protest against detention sometimes achieved its stated aim, such as a mass hunger strike in January 2002 at Woomera. The Australian government suspended the processing of claims from Afghan applicants after the allied invasion of Afghanistan. The hunger strike was started by Afghan detainees, but people from other nationalities soon joined in. At its peak, detainees reported that 370 men, women, and children were on strike, and 70 sewed their lips. ${ }^{22}$ The strike lasted for sixteen days and called for a resumption of processing claims and an improvement in the conditions of detention. Woomera detention centre became difficult to run and attracted significant media attention. The government sent in negotiators and, after initially labelling the strike as "barbaric" and refusing to be "manipulated" by such behaviour, finally agreed to resume processing and improve conditions. ${ }^{23}$ Protests seldom achieved changes in government policies or actions and could be viewed as "failed" by some, but detainees overwhelmingly saw protest action as effective. For detainees, protest was aimed partly at external goals, but it also carried important restorative functions. It was a way to reject the powerless state of "detainee," to re-experience their agency, and to insist upon entry to the polis as political subjects rather than objects.

Especially after a protest, I would feel proud of myself. 'Cause I did something that every free man would do. You know? You are not dead body. You are human, you have got dream. So when you do those things and you come back to your room and think "Oh that was good." Even if we didn't achieve what we wanted, like talking with Immigration or bring Immigration to see us, but at least you feel like the things inside your chest come out. It's better than inside, you get sick. You feel a little bit open and relax, until the next action. (Osman)

Detention centres are extraordinarily controlled environments, where communication, food, activity, movement, and information are tightly regulated and monitored. Detainees have little opportunity to participate in decisionmaking, either at the mundane level of deciding what to eat, or in more fundamental matters such as education, work, or political status. Despite the unequal power relationship between the state and detainees, however, they were not entirely without power. Detainees had less political, material, and semiotic power than the state, but they retained human capacities for thought, speech, and action; they retained agency. Resistance was an important way for detainees to experience their own agency, to take a decision not to eat the food on offer, or to create a disturbance and force a response from authorities such as through self-harming or breaking a piece of camp infrastructure.

Detainees' bodies were a site for the exercise of state sovereignty, but also for detainees to reclaim sovereignty of self. Lacking power over their external environment, they sought to exercise power over their own bodies, and through this to influence their environment and regain a sense of self. Shahin explained the high incidence of hunger strike as a way of experiencing and expressing control over one's own body 
and refusing the omnipotent power of the state: "This would happen because you have no choice. You can't make any decisions in your life. Just to show you are alive, you could make a decision to stop receiving anything in your body. That would show that you were alive, because you could make a decision, in a place that you can't make any decision."

Many former detainees interviewed in this research project had conducted hunger strikes, many of which had achieved the stated aims. Sayed was transferred to a prison when the detention centre became too full. He refused to eat or comply with the prison regime for several days before he was transferred back to detention. Many people said that the official mechanisms for getting anything not routinely provided simply didn't work. Baha'adin explained that if he had a headache and wanted paracetamol, he would be required to lodge a request form, which usually got no response or was granted several days later. He soon learned, as Sayed explained that "if you ask for the request-you don't get it, but if you shout and do something, break something up, you get all these things done." Compliance with the system was largely ineffective and gave people no sense of their own power.

The rates of self-harming are many times higher in detention than in asylum-seeker and refugee populations outside of detention, and it is understood as a sign of poor mental health. ${ }^{24}$ While some detainees also saw it this way, some explained that it was a way of experiencing one's agency. For Issaq, the need to be the initiator of an action and provoke a reaction could be met through cutting himself. His selfharming was an effort to make his actions meaningful.

I wanted to have something to look forward, then slash my wrists and see what's going to happen. You know what I mean? Just something out of ordinary. I mean I know that I'm sitting here and watching that tree, nothing going to happen. I won't get a visa, I won't get out of here and every day going to be the same. But I want to change it. The only power I have to just slash my wrists and see what's going to happen after it. Will it cause attention or not? Will it, you know? You'll hope for a change. To use all what you have to change-I mean, not to get out of detention, but change what's happening now. I mean, I'm sitting here, by doing nothing, nothing would change. But by slashing my wrists there are going to be some action at least. At least five officers are going to come out of the door, nurse is going to come, and all these things. Something going to happen out of ordinary, and in terms of self-harm that was the thing I was looking for. All the power that you have. That's all the power, not just a little of it. That's all you have.

When Issaq was compliant, he could be ignored, but when he self-harmed, the authorities must react. His apparently destructive self-harming paradoxically brought him closer to a place in the world in which his actions were meaningful.
Sam didn't self-harm during his three years in detention, but he was a trusted confidant of many fellow detainees and talked with many people who were self-harming. His explanation is similar to Issaq's, but with less concern for provoking an external reaction than an internal one. He said self-harm “in most cases wasn't a planned thing. It was in most cases out of frustration and it was good in a way that people feel they are real again, they exist, they have power over something-their body. So blood always has a very powerful message, and when people see they can get over their fear and do something, certain thing-harsh thing, they come back to that colour of existence-I have power, I can do things. So I was calling that self-actualization out of frustration in that situation."

The omnipotent power and control of the detention environment and the dehumanization of non-citizenship reached into every aspect of detainees' lives. Their daily routines were micromanaged to such an extent that people lost their sense of self. Protests ranging from breaking a light bulb through to self-harm, hunger strike, and riot were a way of re-experiencing oneself as an agent and of reclaiming human status.

\section{Insisting on a Place in the Polis}

Much detainee resistance was outwardly aimed, that is, there was a specific external target audience and/or goal that the protest sought to achieve. Most was targeted at achieving specific material changes such as getting a light bulb replaced in a room, gaining increased access to telephones, or securing the release of all detainees. These actions were directed primarily at those with explicit power over the detention environment: government officials and security guards. Other forms of resistance were aimed not at government or others directly involved in detention, but at the broader population seeking semiotic change, to effect their representations and position in Australian politics. The target audience of these protests was the Australian and international community (typically through the media, but also through refugee supporters outside), and the aim was to disrupt and unsettle government accounts of their presence in Australia and their actions in detention, and to insert their own narrative alongside their own actions. Detainee protest marked a refusal to allow official government or bureaucratic explanations of their presence and actions to go unchallenged and to insist on active, conscious participation in the political debate.

Detainees saw that they were being used as pawns in Australia's national politics, in particular, that there was political capital for the government in their suffering, and that their suffering was intended to be public and to deter prospective asylum seekers overseas. Ibrahim believed that 
detention was "a plan to punish these people to be honest. This plan has been well managed by someone with high authority in the hierarchy to punish these people and to make them a good example for others ... people are gonna think twice before they come to here." Mehdi reached a similar conclusion: "We were the victim of Australian policy to just stop people coming illegally or something. We were the victim and they wanted to show people that we keep them ... It's not a matter of 'What's your story or what ...?" It's just 'Keep that person.' That's it. They needed to keep some people ... for a long time to say that 'We are strong against these people."”

Emad agreed and added that the theatre of detention gave material proof of the government's strength and resolve to protect Australia's borders and that this was a deliberate strategy to retain government.

Their intention was to give a real strong lesson to the outer world not to come to Australia, oK, by restraining us a group. It's just a misfortunate incident, bad timing for us. Someone wants to give a lesson to the whole world through us. They wanted to say, "If you come to Australia that will be your destiny. You will be treated like this." So, we are subjected to a political, not legal, pressure-a political pressure that the government, at that time, needed to get votes from the ordinary Australian people. And that's what I think happened. In reality one of the main aspects for John Howard election-and he won the election at that time-is that he used immigration as a pressure point, as an element in his campaign to defeat Labor. So we were the source of this election campaign ... Unfortunately they didn't look at us as humans in need for their help. They looked at us as a human that they can use in their election to win and to prevail. And I think that's completely wrong. (Emphasis added)

This analysis is important, because once people had determined that their fate rested not on an individual assessment of each person's claims, but on national political interests, detainees lost faith in the official systems and began to consider alternate actions to resolve their situation. Detainees realized that they needed to establish a political voice for themselves, and reaching the media became a major focus of protest action. There was considerable debate among detainees about how to do this. Many feared that violent protests would reinforce the government representation of them as "uncivilized," a people to be feared, and the perception that their detention was necessary to protect Australia from dangerous people. Many others believed that non-violent protests would go unnoticed. As Issaq argued,

Peacefully doesn't answer anything because there is no journos here. We need to get journos here, and how we can do it? Just go to a town and sit in there until journos gets here? Or just burn the place down and the smoke will bring journalists, you know? That became the main point, just to get the journalists coming there, to make a scene, have a story for a TV or radio or newspaper ... for journalists to fly in there and see us, because they had to come from Adelaide, and it was like 5ook away. So they needed a good story. People sewing their lips in detention was a good story or people burning down the centres was a good story, even though it was relative. But it was getting into a media ... We didn't care about negative publicity. We just wanted to get people to come to detentions and sit.

Dr. Aamer Sultan was initially opposed to hunger strikes, lip-sewing, and violent protests and did not participate in any of these actions during his three years in detention. But looking back, he was less resolute in his objection. He said that he was "very unhappy" about how "the media had shown those aggressive criminals" but that in hindsight

it was a positive thing ... At last the government did the mistake of transferring the camera into there, let the people know at least there are some people there. I mean it's just the beginning of questioning "Who are those people? We don't know about them. We worry about them. Criminals or not, even the most dangerous people in the world, or maybe the other way around, we just want know about it." It's just the fact that this has transferred the argument from a faceless people into actual people doing something bad or good, it doesn't matter.

Most actions were targeted not at government officials or detention centre guards. They were aimed to achieve semiotic change, to insist on a political voice for detainees a place in the polis. Detainees wanted to speak directly to "fellow human beings." After his release, Shahin urged people he met to "write letters to people in detention centres. Get in touch. There is a wall the government has created. And this wall needs to be chipped away from both ways. People from inside are doing their way, for you really the best way is to get to know them. As long as that wall is there, the government can do what they want. And once it is broken or has holes in it, then it's very hard." He was convinced that with direct communication "people could see a human face behind the kind of stories that they had heard or they had seen on the TV. It was very different to be that close."

Shahin's comments reveal an Arendtian understanding of the political sphere, a common space in which people can develop and test their opinions with one another on an equal basis, where membership is confirmed not through formal citizenship, but through recognition of one another displayed through engagement with one another's words and deeds. This kind of encounter draws on conceptions of 
politics in ancient Greece, not as the formal mechanisms of state, nor as the technocratic organization of work, but as a realm in which individual, mutually constituted human beings come together and build a common world. Politics is the arena through which humans present themselves to the world qua human, the space for "appearance" as equal and distinct individuals.

Formal political mechanisms of state are based on representational politics, and asylum seekers had no representative in this realm. They astutely reached out to people outside detention as "fellow human beings." Mohammed explained, "The problem was because we saw a lot of things. Government accuse us, abuse us, and a lot in the TV, and we want to tell 'We are here, we are human beings, we're not more than anything, just we are same as you."' Issaq hoped that the protests would open a space in which he and other detainees could "just reflect our feelings to another human being, just to see us not as a danger but as another human being who escaped from danger."

\section{Detainee Action to Create an Alternative Polis}

Asylum seekers in detention recognized that gaining entry to the formal Australian polis would likely take several years, but the need to belong to a community in which one's speech and action is meaningful, in which one's equality and dignity is recognized, is ever-present. Asylum seekers formed their own political communities inside the detention network. These smaller groups could not ensure people's civic rights in the manner of a nation-state, but they nonetheless established a basis for protecting individual human dignity and exercising human capacities. Through protest, asylum seekers were able to experience their own agency and offer support and recognition to one another. Sayed explained that protest gave him a sense of confidence and agency:

You gain self-confidence because in the environment you are in, you are depending for everything and you abide by the rules, so you have to do like they tell you to do. They set the time for food, you don't have control on anything. When we do something like that, ... it's like a self-independence type of thing. That's what happens. That's why we protest like, because you are achieving something, even though you're not, in the short term, yes you are, but in the long run you won't, but still you will say, you will gain the self-confidence.

Inside detention, detainees discussed and analyzed their situation, their place within Australian politics, the ethics and efficacy of different actions, and ways to speak directly to the Australian public. These communities extended beyond individual relationships and individual detention centres, and across linguistic, religious, and ethnic divides. Within these communities, detainees addressed each other by name, and their opinions were made significant, at least at a very local level through a shared sense of solidarity and belonging. These political communities reassured detainees that they mattered: "A lot of things for other people we done as well to show the support to other things, people that look out at you, 'You are not alone, don't kill yourself. We help you out. We try to help you as well.' Yeah, plenty of things ... They were doing it as well for me too" (Baha'adin).

Emad saw this interconnectedness not only as situational interpersonal care, which is a matter of the private realm, but as fundamental to politics based on mutual respect and recognition, and to the human condition: "So we all try in this world to do something better, because I can't live this life by myself without seeing you smile in this world, because I'll be frustrated at that time. You know, I want to live with other humans who are happy. And I want to see them, you know, achieve their goals in this life."

\section{Conclusion}

Detainees pleaded for recognition as fellow human beings. As Emad put it, "I'm not a perfectionist, I'm not calling for 100 per cent. I need the minimum when someone treats me as a human, not like an object inside the detention centre." Detainees sought to restore their rights by gaining formal entry to the Australian political community through formal refugee applications and through protest. In parallel to using rights-based institutional mechanisms for restoration of the right to have rights, detainees drew on moral and philosophical discourse of human rights, centring on the "human." To be stripped of rights is no distant or academic experience, it is intensely intimate, at once both personal and political. The protests and actions of refugees in detention were aimed at "us," actual people. They were intended to trigger a sentimental, human response and so to insert themselves into the polis, in the absence of bureaucratic recognition, through human-to-human recognition. Arendt's model of human rights as arising only from human determination carries with it the realization that "we" have the power to affect human rights and to decide who falls within the mutual guarantee. Detainees demonstrated their understanding of this view and pushed for recognition by the Australian community beyond the legal and bureaucratic systems. Detainees may be granted a visa and with it, certain legal rights based on re-categorization as a "refugee," but achieving the sort of human rights that Arendt speaks of, of belonging, equality, and distinction relies on deeper political (in the ancient Greek sense) recognition. Shahin expressed it beautifully: 
It is a massive thing to live with the title of "refugee." Which is something that you are bestowed on, you didn't choose it, you didn't pick it. You thought you are making a freedom of movement to get out of a problem that you are in, and now you are in another type of trouble, and there is a title for you to carry on. It is very understandable that a lot of people don't want to be called by that title, and as soon as you go out, that's the first thing that you get. Not many of us feel comfortable with that, but some of us feel like, I don't know, I would like to ... this is something that is on me now. I would like to define it the way that I fulfill it. So yes, I'm a refugee, I'm from Iran, but I'm a human being with these passions, these emotions, this laughter, and these crying moments. You know, like any other human being. And that is the way that I am that refugee.

Lucy Fiske is a Chancellor's Postdoctoral Fellow in the Faculty of Arts and Social Sciences, University of Technology Sydney. The author may be contacted at Lucy.Fiske@uts.edu.au.

\section{Notes}

1 The International Detention Coalition maintains an up-todate database of locations, conditions, and populations of immigration detention regimes globally. Further information can be found at idcoalition.org/detention-database/.

2 The conditions of Australian detention centres have been well documented. For more detail see, for example, Australian Human Rights Commission, The Forgotten Children: National Inquiry into Children in Immigration Detention (Sydney: Australian Human Rights Commission, 2014); Linda Briskman, Susie Latham, and Chris Goddard, Human Rights Overboard: Seeking Asylum in Australia (Melbourne: Scribe Publications, 2008); Lucy Fiske, "Riotous Refugees or Systemic Injustice? A Sociological Examination of Riots in Australian Immigration Detention Centres," Journal of Refugee Studies 27, no. 3 (2013): 382-402; United Nations Working Group on Arbitrary Detention, Civil and Political Rights, Including the Question of Torture and Detention: Report of the Working Group on Arbitrary Detention. Visit to Australia, document E/CN.4/2003/8/ Add.2 (Geneva: United Nations Commission on Human Rights 59th Session, October 24, 2002).

3 See, for example, Michael Clyne, "Words Excusing Exclusion," in Seeking Asylum in Australia 1995-2005: Experiences and policies, ed. Susan Aykut and Jessie Taylor, 21-8 (Melbourne: Monash University Institute for Public History, 2006); Department of Immigration and Multicultural and Indigenous Affairs, "Arson at Woomera Detention Facility," news release, 18 December 2001; Department of Immigration and Multicultural and Indigenous Affairs, "Woomera Officers Targeted in Orchestrated Attack," news release, 31 December 2002.

4 Semi-structured interviews were conducted with eighteen former detainees in 2008 and 2009 in Perth, Sydney, and
Melbourne, Australia. Respondents had been detained between 1999 and 2005 for eight months to five years, with the majority having been detained for more than two years. Although this was a qualitative research project, there was a definite link between the length of detention and the number and types of protest actions engaged in. Most interviews were conducted individually, with one focus group and two pairs. Interviews typically lasted 90-120 minutes and began with an open-ended question: "Describe a typical day in detention." The interviewer then probed for more detail, depending on the responses of participants. Participants originated from Afghanistan, Iran, Iraq, and Jordan, and one was a stateless person. All respondents were men. The people interviewed in this research were all detained as asylum seekers, and all except one had been granted refugee status. I use the terms refugee and detainee throughout, as it was their status as detainees that underpinned much protest, rather than their status as refugees. The research is published in full in Lucy Fiske, Human Rights, Refugee Protest and Immigration Detention (London: Palgrave Macmillan, 2016).

5 The research presented here used inductive analysisstarting with the explanations of refugees subjected to immigration detention, and using this to direct my search for theoretical and analytical frames. Hannah Arendt's work on human rights and her thoughts on "the human condition" resonated with much of what was said by the people interviewed for this research. While Arendt's work has at times been criticized for drawing too neat a distinction between the public and private realm, her work, particularly with its emphasis on a constructivist approach to human rights and her insistence that actual human beings remain at the centre of human rights (rather than nature, an abstract man, or legal/bureaucratic categories) that makes her work so useful in understanding the language of human rights used by asylum seekers in detention. For more on Arendt's approach to human rights and critiques of her work, see, for example, Seyla Benhabib, "Feminist Theory and Hannah Arendt's Concept of Public Space," History of the Human Sciences 6, no. 2 (1993): 97-114; Lewis P. Hinchman and Sandra K. Hinchman, Hannah Arendt: Critical Essays (Albany: State University of New York Press, 1994); Serena Parekh, Hannah Arendt and the Challenge of Modernity: A Phenomenology of Human Rights (New York: Routledge, 2008).

6 The dehumanization of immigration detention has not been the subject of extensive academic attention. Studies that have explored it include Guy Coffey, Ida Kaplan, Robyn Sampson, and Maria Tucci, "The Meaning and Mental Health Consequences of Long-Term Immigration Detention for People Seeking Asylum," Social Science and Medicine 70 (2013): 2070-9; Daniela DeBono, "Less than Human: The Detention of Irregular Immigrants in Malta," Race and Class 55, no. 2 (2013): 60-81. 
7 Pseudonyms have been used to protect informants' identity, except for Aamer, Farshid, and Shahin, who have all spoken publicly of their experiences in detention and have consented to using their real names. And I have chosen to reproduce the exact syntax and grammar of the speakers in the quoted text.

8 Hannah Arendt, The Human Condition (Chicago: University of Chicago Press, 1958), 179.

9 Boatperson is a term used in Australia to refer to asylum seekers who have arrived in Australia by boat without prior authorization. It has some derogatory connotations, particularly in casting such people as morally dubious and untrustworthy. Boatpeople are subject to legal frameworks and policies that are different from those for asylum seekers arriving by plane. There are movements underway to reclaim the term boatpeople as "genuine" refugees and to counter the pejorative use of the term.

10 Hannah Arendt, The Origins of Totalitarianism (Orlando, FL: Harcourt Publishing, 1976), 301-2.

11 Serena Parekh, "A Meaningful Place in the World: Hannah Arendt on the Nature of Human Rights," Journal of Human Rights 3, no. 1 (2004): 41.
12 Arendt, Origins, 296.

13 Ibid., 297.

14 Arendt, Human, 22-5.

15 Arendt, Origins, 297.

16 Arendt, Human, 179.

17 Ibid., 176.

18 Benhabib cited in Parekh, "Meaningful Place," 52.

19 Arendt, Human, 8.

20 Arendt, Origins, 301.

21 Arendt, Human, 243.

22 Anne Barker, "Afghan Youths Threaten Suicide at the Woomera Detention Centre," 7.30 Report, АBC Television, 28 January, 2002, http://www.abc.net.au/7.30/content $/ 2002 / \mathrm{s} 468052 . \mathrm{htm}$.

23 Natascha Klocker and Kevin Dunn, "Who's Driving the Asylum Seeker Debate? Newspaper and Government Representations of Asylum Seekers," Media International Australia 109 (2003): 71-92.

24 Commonwealth Ombudsman (Australia), Suicide and Self-Harm in the Immigration Detention Network, report no. 2/2013 (Canberra: Commonwealth Ombudsman, 2013).

(C) Lucy Fiske, 2016. This open-access work is licensed under a Creative Commons Attribution-NonCommercial 4.0 International License, which permits use, reproduction and distribution in any medium for non-commercial purposes, provided the original author(s) are credited and the original publication in Refuge: Canada's Journal on Refugees is cited. 